\title{
Foreign Direct Investment in Nepal's Hydropower Development
}

\section{Pradeep Gangol}

\begin{abstract}
The fund for Foreign Direct Investment (FDI) is globally limited and overstretched. Therefore, Nepal needs to go the extra mile in offering a competitive investment environment to attract FDI flows into Nepal's hydropower development. It literally means that our investment policies and laws should be more competitive compared to that of other countries like Vietnam, Cambodia and Bangladesh etc.
\end{abstract}

Key words: FDI, power development agreement, hydropower, Nepal

\section{Introduction}

Goreign Direct Investment (FDI) has been defined as a cross border investment done by foreign companies in a host country. Nepal has good investment prospects in hydropower, tourism and information technology.

Nepal took on a liberalization strategy in the early 1990s. The Foreign Investment and Technology Transfer Act (FITTA), 1992 came into place to encourage FDIs into the country. There is a huge potential in the hydro-power sector of the country with a feasible generation capacity of 42,000 MW. However, only a very small amount of it has been utilized so far leaving huge untapped potential for hydropower energy. According to the Nepal Economic Growth Agenda, 2012, there is a deficit of 520 MW of electricity during the winter season and people have to live under load-shedding for several hours a day. Current production has not even met local demand. It is well known fact that FDIs and economic growth have a strong relationship. Hydro-electricity produced in Nepal can also cater to the growing energy demand of neighboring countries. Nepal's unique mountainous terrain and rich water resources gives foreign investors a great advantage by virtue of its location for investing in energy to supply to rapidly growing India and China. FDI has the ability to sustain a high trajectory of economic growth in a host country.

\section{Problem Areas}

Nepal's FDI policy has been found to be too limited to exploit the potential for FDI inflows into the country and truly reap the benefits of FDIs.

At the policy level, Nepal has formulated a liberal and open Foreign Direct Investment and Technology Transfer Act-1992 with a limited negative list. It has opened more sectors of the Nepalese economy for foreign investment with the guarantee of non-nationalization, repatriation of profit, share transfer and dividend sharing. In addition to this, Nepal has also signed Bilateral Investment Protection and Promotion Agreements (BIPPA) with the following six countries in chronological order - France, Germany, UK, Mauritius, Finland and India. It has covered the provision which provides compensation to the investors whose investments suffer losses due to war, armed conflict and a state of national emergency. These are all positive steps for encouraging FDI into the country.

Mega Projects like the Arun III (90o MW), Upper Karnali (900 MW), Upper Marsyangdi-A (600 MW), and Lower Tamakoshi (400 MW) are in the process of negotiations with the Government of Nepal for signing Project Development Agreements (PDA). The first three projects are export oriented projects while the the fourth is looking for the local markets. These companies could not start their construction work due to the absence of Power Trade Agreement (PTA) between India and Nepal, and a Surcharge Tax of $2 \%$ charged by India on electricity exported from Nepal. Though, the Government of India is reported to have waived the $2 \%$ Surcharge Tax, for import of power from Nepal, it is yet to be confirmed officially. Similarly, the availability of a market is an incentive for investors. Nepal is close to India, which is a very large market. In the case of investment in hydropower development, foreign investors want to have a bankable Project Development Agreement (PDA) and a bankable Power Purchase Agreement (PPA). Moreover, it is natural that they want to have a fair rate of return on their investment. Therefore, the main test of the PPA and PDA lies in guaranteeing the fair rate of return on investment. The Government of Nepal has many options to ensure profit on their investment like extending the concession period, exempting the VAT, extending the Income Tax holiday period, offering attractive Power Purchase Rates etc. Taking into consideration the fact that the hydropower plants built under the BOOT model are ultimately handed over to the government, government should be more liberal to offer incentives to the investors. After all, more hydropower plants mean that more assets are created for the government, and eventually mean more revenue that can be invested in health, education, poverty alleviation and infrastructural development.

\section{Recommendations}

Therefore, it is high time that we revisit those investment policies in order to increase FDI inflows into Nepal. The difficulties that the investors are facing include the process of termination, repatriation, sharing of risks including that of hydrological risks, foreign exchange risks, payment guarantee, policy stability, issues of land acquisition, and increased cost of transactions, 
infrastructure, government policies and political instability. There is much work that needs to be done to create a favorable business environment for investors.

The FITTA 1992, for example, was amended in 1996 so that it guarantees full repatriation of the amount received from the sale of equity, profits or dividend and interest on foreign loan. Foreign currency earners are permitted to retain cent percent of their foreign currency earnings and are free to maintain foreign currency deposits with local banks. However, the implementation of this provision involves the central bank and several other government agencies. The process itself is cumbersome and many investors complain of not being able to repatriate profits.

Nepal needs foreign capital to take advantage of its existing resources and promote growth in the economy. While foreign aid is one option, foreign investment brings better outcomes.

The Nepal Government needs to urgently focus on the following issues to attract FDI in Nepal's hydropower development.

\section{Bilateral Agreements}

Bilateral Investment Treaties (BITs) should be signed with those countries from where there are higher chances of inflow and outflow of large investments, especially in hydropower. It also gives a positive message to other foreign investors, showing that the host country is seriously committed to safeguarding the interests of foreign investors.

\section{Power Trade Agreement}

An umbrella type Power Trade Agreement (PTA) with India should be signed as soon as possible and the $2 \%$ Customs Tax with India should be removed because, practically, it makes the electricity produced in Nepal expensive. Such agreements create the necessary environment for the construction of large hydropower projects such as the Tamakoshi III, Upper Karnali, Arun III, etc.

\section{Increased Cost of Transaction}

The approval process of FDI should be made simple and automatic so that there will be less contacts with the officials. It helps reduce corruption and other bureaucratic hassles.

\section{PDA and PPA}

The Project Development Agreement (PDA) and Power Purchase Agreement to be signed with the developers of domestic hydropower projects should be bankable enough to encourage the international financial institutions to invest in Nepal's hydropower development.

The main crux of both PPA and PDA lies in ensuring a fair return to investors on their investment and also fair revenue to the government for allowing to exploit the natural resources i.e. water resources of Nepal.

\section{Future Prospects}

There has been considerable interest recently in the SAARC countries to build a common grid called SAARC Grid. The first cross border transmission line between Nepal and India is now under construction. There is already power trade between India and Bhutan,and, India and Bangladesh. The under-sea transmission line between India and Sri Lanka will soon come into operation. Pakistan has recently expressed its plan to import power from India. All these developments will finally lead to the formation of a common grid, which will help in the optimum utilization of coal resources of India and Pakistan, hydropower resources of Nepal and Bhutan, and gas resources of Bangladesh. It will open up the huge power market for Nepal's hydropower development.

\section{Conclusion}

As the proverb goes, "Strike the iron, when it is hot “. The Government of Nepal should be more liberal this time in welcoming FDI into Nepal's hydropower development by making appropriate changes (not cosmetic ones) in its Investment Laws and Policies. There is a strong possibility of huge inflow of FDIs into Nepal's hydropower development, provided that the Nepal Government wakes up to the call of the hour and "fine tunes" its investment policies.

It is hoped that Nepal will sense the "now or never" opportunity for hydropower development in Nepal, given the huge power market in its proximity, suitable mountain topography and rich water resources.

Mr. Gangol, is a senior hydropower engineer with M.Sc. degree in Civil/Hydraulic Engineering from the Technical University of Budapest, Hungary and Post Graduate Diploma in Hydropower Development from the Norwegian Institute of Technology, Norway. At present, he is associated with the Nepal Water and Energy Development Company Private Limited (NWEDC), as its Liaison Manager. NWEDC is developing 216 MW Upper Trishuli-1 Hydropower Project.

Corresponding address: pradeep.gangol@nwedc.com. $n p$

The views expressed here are his personal ones. 